SAT0604

SECONDARY HEMOPHAGOCYTIC SYNDROME: RETROSPECTIVE STUDY ACCORDING TO THE UNDERLYING DISEASE

C.A. Egües Dubuc ${ }^{1}$, J.A. Valero ${ }^{1}$, A. De Diego ${ }^{1}$, J.R. Furundarena ${ }^{2}$, O. Maiz ${ }^{1}$, L. M. López ${ }^{1}$, J.J. Cancio ${ }^{1}$, E. Uriarte', M.M. Yagüe ${ }^{1}$, J. Calvo Alen ${ }^{3}$, J.

M. Belzunegui $1 .{ }^{1}$ Rheumatolgy, ${ }^{2}$ Hematology, Donostia University Hospital, San Sebastián; ${ }^{3}$ Rheumatolgy, Araba University Hospital, Vitoria, Spain

Background: Secondary Hemophagocytic Syndrome (SHS) is associated with Hematoncologic (HO), Autoimmune (Al) diseases [such as Systemic Lupus Erythematosus (SLE) or Adult's Still Disease (ASD)] and in a lower frequency with Infections (Inf.) and Tumours (Tum.).

Objectives: Describe the demographic and underlying disorders during hospital admission of patients with SHS during the period December/2005-January/2018. Methods: A retrospective search of patients diagnosed with SHS and bone marrow biopsy (B.M.O.) with hemophagocytosis was performed. Patients were grouped in: Al, HO, Inf, Tum. and SHS without cause (wc). The variables were: sex, age, diagnosis of the underlying disease, fever, organomegaly, laboratory findings, days of hospital stay, days from admission to B.M.O. and mortality.

Results: A total of 27 patients were found. table 1 shows the characteristics of the groups. Al $\square \square$ diseases found were: 5 SLE, 2 ASD, 1 Rheumatoid Arthritis and 1 Sclerosing Disease Related to IgG4. The HOs were: 4 Myelodysplastic Syndrome, 3 Non-Hogkins Lymphomas, 2 Acute Leukemias, 1 Extranodal Lymphoma of Natural Killer Cells (NKC) and 1 Gastric Plasmocytoma. Inf. were: 1 infection of Pneumocystis in the recent diagnosis of HIV and Gastroenteritis by Campylobacter yeyuni. One Tum. in a patient with Glioblastoma multiforme who received temozolomide. During the follow-up no recurrence of SHS was observed. The SCD25 and cytolytic activity of the NKC were not done.

Abstract SAT0604 - Table

\begin{tabular}{|c|c|c|c|c|c|c|}
\hline & $\begin{array}{l}\text { All }(n=27) \\
\text { (P25-P75 } \\
\text { or\%) }\end{array}$ & $\begin{array}{c}\text { Al }(\mathbf{n}=9) \\
(\mathrm{P} 25-\mathrm{P} 75 \\
\text { or } \%)\end{array}$ & $\begin{array}{c}\text { HO }(n=11) \\
\text { (P25-P75 } \\
\text { or\%) }\end{array}$ & $\begin{array}{l}\text { Inf. }(\mathbf{n}=\mathbf{2}) \\
\text { (P25-P75 } \\
\text { or\%) }\end{array}$ & $\begin{array}{l}\text { Tum. } \\
(n=1)\end{array}$ & $\begin{array}{c}\text { SHSwc } \\
(n=4) \\
(\mathrm{P} 25-\mathrm{P} 75 \\
\text { or } \%)\end{array}$ \\
\hline Years & $\begin{array}{c}57(40- \\
70)\end{array}$ & $\begin{array}{c}40(30- \\
56)\end{array}$ & $\begin{array}{c}67(57,4- \\
72,5)\end{array}$ & $\begin{array}{c}46(38- \\
23)\end{array}$ & 78 & $64(55-72)$ \\
\hline Female sex & $15(56)$ & $7(77)$ & $3(27)$ & $1(50)$ & 0 & $4(100)$ \\
\hline $\begin{array}{l}\text { Debut of the } \\
\text { underlying } \\
\text { diseases }\end{array}$ & $16(59)$ & $6(67)$ & $4(36)$ & $2(100)$ & 0 & $4(100)$ \\
\hline $\begin{array}{l}\text { Days of hospital } \\
\text { stay }\end{array}$ & $\begin{array}{c}35(20- \\
62)\end{array}$ & $\begin{array}{c}26(10- \\
38)\end{array}$ & $\begin{array}{c}60(40- \\
91)\end{array}$ & $\begin{array}{c}23(20- \\
27)\end{array}$ & 28 & $38(20-56)$ \\
\hline $\begin{array}{l}\text { Days from } \\
\text { admission to B.M. } \\
\text { O. }\end{array}$ & $\begin{array}{c}16(10- \\
30)\end{array}$ & $12(5-16)$ & $\begin{array}{c}24(13- \\
37)\end{array}$ & $\begin{array}{c}14(13- \\
16)\end{array}$ & 13 & $42(28-49)$ \\
\hline Fever & $27(100)$ & $9(100)$ & $11(100)$ & $2(100)$ & 1 & $4(100)$ \\
\hline Organomegaly & $16(59)$ & $5(55.5)$ & $8(72.7)$ & $2(100)$ & 0 & $1(25)$ \\
\hline $\begin{array}{l}\text { Haemoglobin (mg/ } \\
\text { dl) }\end{array}$ & $\begin{array}{c}7(6,4- \\
7,7)\end{array}$ & $\begin{array}{c}7,3(6,7- \\
8,3)\end{array}$ & $\begin{array}{c}6,6(6- \\
7,2)\end{array}$ & $\begin{array}{c}7,6(7,4- \\
7,7)\end{array}$ & 8,6 & $7(6,7-8)$ \\
\hline Platelets $\left(10^{3} / \mathrm{ul}\right)$ & $12\left(^{5-32}\right.$ & $\begin{array}{c}17,3(12- \\
72)\end{array}$ & $4(0.6-15)$ & $\begin{array}{c}9,5(9- \\
10)\end{array}$ & 5 & $\begin{array}{c}93(34- \\
165\end{array}$ \\
\hline Leukocytes (/ul) & $\begin{array}{l}1200 \\
(340- \\
2715)\end{array}$ & $\begin{array}{c}1860 \\
(1400- \\
3340)\end{array}$ & $\begin{array}{c}170(20- \\
685)\end{array}$ & $\begin{array}{c}2050 \\
(1530- \\
2570)\end{array}$ & 480 & $\begin{array}{c}4170 \\
(3343- \\
5135)\end{array}$ \\
\hline Neutrophils (/ul) & $\begin{array}{c}580(0- \\
1280)\end{array}$ & $\begin{array}{l}890 \\
(650- \\
1130)\end{array}$ & $0(0-190)$ & $\begin{array}{l}1160 \\
(580- \\
1740)\end{array}$ & 230 & $\begin{array}{c}2190 \\
(1285- \\
3453)\end{array}$ \\
\hline $\begin{array}{l}\text { Triglycerides (mg/ } \\
\text { dl) }\end{array}$ & $\begin{array}{c}341(241- \\
422)\end{array}$ & $\begin{array}{c}411 \\
(254- \\
417)\end{array}$ & $\begin{array}{c}340(275- \\
367)\end{array}$ & $\begin{array}{c}373(323- \\
422)\end{array}$ & 149 & $\begin{array}{c}418(279- \\
520)\end{array}$ \\
\hline Fibrinogen (mg/dl) & $\begin{array}{c}172(117- \\
381)\end{array}$ & $\begin{array}{c}297 \\
(116- \\
450)\end{array}$ & $\begin{array}{c}147(139- \\
321)\end{array}$ & $\begin{array}{l}214(214- \\
2014)\end{array}$ & 117 & $\begin{array}{c}172(127- \\
224)\end{array}$ \\
\hline Ferritin (ug/L) & $\begin{array}{l}15300 \\
(5015- \\
28729)\end{array}$ & $\begin{array}{l}13225 \\
(4864- \\
15359)\end{array}$ & $\begin{array}{c}16751 \\
(15664- \\
47537)\end{array}$ & $\begin{array}{c}10347 \\
(10051- \\
10642)\end{array}$ & & $\begin{array}{l}14766 \\
(3840- \\
25757)\end{array}$ \\
\hline $\begin{array}{l}\text { Oxalacetic } \\
\text { glutamic } \\
\text { transaminase (UI/l) }\end{array}$ & $\begin{array}{c}144(74- \\
399)\end{array}$ & $\begin{array}{c}402 \\
(325- \\
1080)\end{array}$ & $\begin{array}{c}91(72- \\
187)\end{array}$ & $\begin{array}{c}79(51- \\
106)\end{array}$ & 54 & $\begin{array}{c}127(91- \\
315)\end{array}$ \\
\hline $\begin{array}{l}\text { Transaminase } \\
\text { aspartate } \\
\text { aminotransferase } \\
\text { (UI/I) }\end{array}$ & $\begin{array}{c}177(65- \\
342)\end{array}$ & $\begin{array}{c}437 \\
(325- \\
596)\end{array}$ & $\begin{array}{c}108(88- \\
255)\end{array}$ & $\begin{array}{c}133(83- \\
184)\end{array}$ & 88 & $\begin{array}{c}103(28- \\
232)\end{array}$ \\
\hline $\begin{array}{l}\text { Lactate } \\
\text { dehydrogenase } \\
\text { (UI/I) }\end{array}$ & $\begin{array}{c}721(494- \\
976)\end{array}$ & $\begin{array}{c}845 \\
(708- \\
959)\end{array}$ & $\begin{array}{c}638(339- \\
1133)\end{array}$ & $\begin{array}{c}597(519- \\
674)\end{array}$ & 426 & $\begin{array}{c}786(497- \\
1797)\end{array}$ \\
\hline Mortality & $11(4)$ & $1(11)$ & $7(37)$ & $1(50)$ & 0 & $2(50)$ \\
\hline
\end{tabular}

Conclusions: Patients with SHS to $\mathrm{HO}$ disease had a high mortality and a longer hospital stay compared to the rest of the groups. Practically all patients met all diagnostic criteria, the most frequent were fever, pancytopenia and hyperferritinemia.

Disclosure of Interest: None declared

DOI: 10.1136/annrheumdis-2018-eular.6184

\section{SAT0605 THE PRESENCE OF UVEITIS PREDICTS THE RESPONSE TO THE INTERLEUKIN (IL)-1 INHIBITORS ANAKINRA AND CANAKINUMAB IN BEHÇET'S DISEASE}

C. Fabiani ${ }^{1}$, A. Vitale ${ }^{2}$, G. Emmi ${ }^{3}$, G. Lopalco ${ }^{4}$, D. Rigante ${ }^{5}$, J. Sota ${ }^{2}$, I. Orlando ${ }^{2}$, B. Frediani ${ }^{2}$, R. Franceschini ${ }^{2}$, M. Galeazzi ${ }^{2}$, F. lannone ${ }^{4}$, G.M. Tosi ${ }^{2}$, L. Cantarini ${ }^{2}$. ${ }^{1}$ Humanitas Clinical and Research Center, Milan; ${ }^{2}$ University of Siena, Siena; ${ }^{3}$ University of Florence, Florence; ${ }^{4}$ University of Bari, Bari; ${ }^{5}$ Università Cattolica Sacro Cuore, Rome, Italy

Background: In recent times IL-1 inhibition has been proposed as an intriguing therapeutic option in Behçet disease (BD) patients with multi-drug resistant manifestations. ${ }^{1}$ However, despite the good clinical results obtained during the last years, cases of BD nonresponsive to anakinra (ANA) and canakinumab (CAN) have also been identified. This evidence has induced to suspect the existence of specific subsets of patients characterised by a more pronounced IL-1 driven pathogenesis. ${ }^{2,3}$

Objectives: To identify predictive factors of response to interleukin (IL)-1 inhibition among demographic, clinical and therapeutic data in patients with (BD).

Methods: BD patients treated with ANA or CAN were enrolled. Patients were divided into 2 groups according to the clinical response: group 1 included subjects showing a treatment duration of at least 52 weeks and no secondary inefficacy during the first follow-up year; the remaining patients were included in the group 2. Demographic, clinical and therapeutic data were analysed to identify significant differences between groups.

Results: Eighteen patients (50\%) were included in group 1 and 18 (50\%) in group 2. A better response to IL-1 inhibitors was significantly more common among patients with BD-related uveitis $(p=0.006)$ and patients with a longer disease duration $(\mathrm{p}=0.03)$.

Conclusions: IL-1 blockade is effective in $\mathrm{BD}$, especially in the subset of patients presenting ocular involvement and in those with long-lasting disease.

\section{REFERENCES:}

[1] Vitale A, Rigante D, Lopalco G, Selmi C, Galeazzi M, lannone F, Cantarini L. Interleukin-1 inhibition in Behçet's disease. Isr Med Assoc J 2016;18(34):171-6.

[2] Vitale A, Rigante D, Caso F, Brizi MG, Galeazzi M, Costa L, et al. Inhibition of interleukin-1 by canakinumab as a successful mono-drug strategy for the treatment of refractory Behçet's disease: a case series. Dermatology 2014;228(3):211-4. doi:10.1159/000358125

[3] Cantarini L, Vitale A, Scalini P, Dinarello CA, Rigante D, Franceschini R, et al. Anakinra treatment in drug-resistant Behcet's disease: a case series. Clin Rheumatol 2015;34(7):1293-301. doi:10.1007/s10067-013-2443-8

Disclosure of Interest: None declared

DOI: 10.1136/annrheumdis-2018-eular.1170

\section{SAT0606 DISEASE MODIFYING ANTI RHEUMATIC DRUGS IN THE TREATMENT OF SAPHO SYNDROME: SYSTEMATIC LITERATURE ANALYSIS}

M. Monet ${ }^{1}$, C. Prati ${ }^{1}$, X. Guillot ${ }^{1}$, M. Sondag ${ }^{1}$, F. Verhoeven ${ }^{1}$, F. Aubin ${ }^{2}$, D. Wendling ${ }^{1} \cdot{ }^{1}$ Rheumatology; ${ }^{2}$ Dermatology, CHRU Besançon, Besançon, France

Background: SAPHO (Synovitis Acne Pustulosis Hyperostosis Osteitis) Syndrome is a rare, heterogeneous clinical entity with cutaneous and osteoarticular expression. The therapeutic management is not codified and there is no validated evaluation tool for SAPHO syndrome.

Objectives: To perform a systematic analysis of the literature in order to evaluate the effects of DMARDs in SAPHO syndrome.

Methods: Bisphosphonates, conventional and targeted synthetic DMARDs, antiTNF alpha, and other biologics have been subjected to advanced Pubmed research. Treatment was considered effective when the patient validated the response criteria defined in the study or if at least partial benefit was obtained for a minimum of three months. The different treatments were ranked according to their effectiveness rate in three interest groups and then grouped by therapeutic class to determine an overall response rate. These rates led to the calculation of an efficacy index weighted by the number of patients treated in the subgroup (molecule or therapeutic class) compared to the total number of patients in our study.

Results: Treatment efficacy was evaluable in 284 of the 292 patients analysed. The clinical presentation of cases was reported in 205 patients for osteoarticular 